\title{
Constitutional silence on election postponement in Ethiopia amidst a pandemic: A critique of constitutional interpretation
}

\author{
Marew Abebe Salemot \\ Lecturer of Federalism at Debark University, \\ Debark, Ethiopia, \\ marewobu@gmail.com
}

\begin{abstract}
Election postponement in Ethiopia, due to the COVID-19 pandemic, has raised critical constitutional questions that have never been really thought before in the country's constitutional law jurisprudence. This is because the state of emergency measure in Ethiopia, due to the spread of COVID-19, is in conflict with constitutional deadlines for elections. The constitutional lacuna is complicated by the absence of explicit constitutional provisions that indisputably govern election postponement. Although any legal measures to postpone election schedule and pass constitutional deadlock is far from simple, the Ethiopian government has suggested four possible 'options' to the constitutional dilemma: dissolving the parliament, declaring state of emergency, amendment of the Constitution and constitutional interpretation. Finally, the House of Federation (HoF), the Ethiopian upper House entrusted to interpret the constitution decided and postponed the election indefinitely until the pandemic no longer poses a risk to public health confirmed by the parliament which has direct vested interest in the outcome. This research investigates whether the constitutional interpretation option adheres to the premises of the Ethiopian Constitution or is it extra constitutional. Accordingly, the HoF provided superficial analysis and fallacious reasoning and failed to meaningfully grapple with the serious constitutional issues. The constitutional interpretation is not constitutionally bound and is defective. The manner the HoF managed the constitutional vacuum concerning election postponement, indisputably, was 'constitutional interpretation' by name but a political decision in practice.
\end{abstract}

Key words: COVID-19, Election deferral, Ethiopia, Constitutional Interpretation, Second Chamber, political decision

Conflicts of interest. The author declared no conflicts of interest.

Article received 2 nd November 2020

Article accepted 15th April 2021

\section{For citation:}

Salemot Marew Abebe (2021) Constitutional silence on election postponement in Ethiopia amidst a pandemic: A critique of constitutional interpretation. RUDN Journal of Law. 25 (2), 714-731. DOI: 10.22363/2313-2337-2021-25-2-714-731

(C) Salemot Marew Abebe, 2021

This work is licensed under a Creative Commons Attribution 4.0 International License https://creativecommons.org/licenses/by/4.0 


\title{
Конституционное умолчание отсрочки выборов в Эфиопии в условиях пандемии: критика конституционного толкования
}

\author{
Марев Абебе Салмот \\ Университет Дебарка, \\ 2. Дебарк, Эфиопия, \\ marewobu@gmail.com
}

\begin{abstract}
Аннотация. Отсрочка выборов в Эфиопии из-за пандемии COVID-19 подняла важные конституционные вопросы, о которых раньше никогда не задумывались в судебной практике страны. Это связано с тем, что чрезвычайное положение в Эфиопии, направленное на сдерживание распространения COVID-19, противоречит конституционным срокам проведения выборов. Конституционная лакуна осложняется отсутствием четких конституционных положений, регулирующих неоспоримо отсрочку выборов. Хотя любые правовые меры по переносу графика выборов и выходу из конституционного тупика далеко не просты, правительство Эфиопии предложило четыре возможных «варианта» решения конституционной дилеммы: роспуск парламента, объявление чрезвычайного положения, поправка к Конституции и ее толкование. Наконец, Палата Федерации (HoF), верхняя палата Эфиопии, которой было поручено толковать конституцию, приняла решение и отложила выборы на неопределенный срок до тех пор, пока пандемия не перестанет представлять опасность для здоровья населения, что было подтверждено самим парламентом, который непосредственно заинтересован в их результатах. В этом исследовании изучается, соответствует ли вариант конституционного толкования положениям Конституции Эфиопии или он является дополнительным конституционным. Соответственно, HoF представила поверхностный анализ и ошибочные аргументы и не смогла серьезно решить серьезные конституционные проблемы. Конституционное толкование не является конституционным, оно ошибочно. Таким образом HoF якобы устранила конституционный вакуум в отношении отсрочки выборов; бесспорно, это было так называемое «толкование конституции», а на самом деле на практике - это политическое решение.
\end{abstract}

Ключевые слова: COVID-19, отсрочка выборов, Эфиопия, конституционное толкование, вторая палата, политическое решение

Конфликт интересов: Автор заявляет об отсутствии конфликта интересов.

Дата поступления в редакиию: 2 ноября 2020 г.

Дата принятия к печати: 15 января 2021 г.

\section{Для цитирования:}

Salemot Marew Abebe. Constitutional silence on election postponement in Ethiopia amidst a pandemic: A critique of constitutional interpretation // RUDN Journal of Law. 2021. T. 25. № 2 . C. 714 -731. DOI: 10.22363/2313-2337-2021-25-2-714-731

\section{Introduction}

The Coronavirus (COVID-19) pandemic, which outbreak in China in late 2019, has forced most states to impose either partial or complete lockdown. Some others have declared a state of emergency to curb the spread of the pandemic ${ }^{1}$. The declaration of

\footnotetext{
${ }^{1}$ Emergency Measures and COVID-19: Guidance Organization for Higher Commission for Human Rights 2020. Available at: https://www.Ohchr.Org/Documents/Events/Emergencymeasure_COVID19.Pdf. [State of
} 
state of emergency, during the coronavirus times ${ }^{2}$, is in coetaneous with the election period to certain states and has placed unprecedented pressure on states as to whether to hold or postpone scheduled elections, resulting in controversies in either case (Antonio, 2020). Only 36 states and territories have decided to hold national or subnational elections as originally planned despite concerns related to COVID-19 and at least 70 countries and territories across the globe have decided to postpone national and subnational elections due to COVID- $19^{3}$.

While some states have constitutional provisions or legal frameworks to deal with election postponements in certain circumstances, such as political crises, the death of elected officials or natural disasters, some others have neither constitutional provisions nor any legal frameworks to do so (Sead, 2018).

Following the report of the first case of COVID-19 in Ethiopia on 13 March 2020 , the government restricted public movements and closed offices and schools ${ }^{4}$. On March 31, the National Electoral Board of Ethiopia submitted a proposal to the House of Peoples Representatives, approved on 30 April 2020, to postpone the sixth national election, which was scheduled to be held in August 2020, for an unspecified time ${ }^{5}$. A week after the de facto lockdown, a formal state of emergency was declared all over the country for five months (on 8 April 2020) ${ }^{6}$ and had effectively postponed the election schedule. But the postponement of elections in Ethiopia due to the COVID-19 pandemic has raised a critical constitutional question that has never been thought before in the country's constitutional law jurisprudence nor discussed in academic publications.

This was because the state of emergency measure in Ethiopia, due to COVID-19, was in conflict with constitutional deadlines for elections. The constitutional lacuna was complicated by the absence of explicit constitutional provisions that indisputably govern election postponement.

By the end of September 2020, Ethiopia faced two scenarios: a state with no government (as the term of office of the incumbent government ends then) or having

\footnotetext{
Emergency], In a general sense, involves "Governmental action taken during an extraordinary national crisis that usually entails broad restrictions on human rights in order to resolve the Crisis".

2 At Least 70 countries and territories across the globe have decided to postpone national and subnational elections due to COVID-19.

${ }^{3}$ Global Overview of COVID-19 Impacts On Elections (2020), https://Www.Idea.Int/News-Media/ Multimedia-Reports/Global-Overview-Covid-19-Impact-Elections. International IDEA's Global Overview of COVID-19: Impact On Elections lists the countries that conducted elections under COVID-19 as of March 2020, among which: Australia (Local Elections in Queensland); Dominican Republic (Municipal Elections); France (Local Elections); Germany (Local Elections in Bavaria); Guyana (General Elections); Israel (General Elections); Mali (General Elections); Switzerland (Local Elections in Lucerne) and Vanuatu (General Elections).

${ }^{4}$ Zemelak, A. (2020) Federalism and the COVID-19 Crisis: Perspective from Ethiopia. Forum of Federation. Available at: http://www.forumfed.org/wp-content/uploads/2020/04/EthiopiaCOVID-1.pdf [Accessed 17th July 2020].

5 International Foundations for Electoral Systems: Elections Postponed Due to COVID. August 20, 2020, 1-8. Available at: http//Ohfgljdgelakfkefopgklcohadegdpjf/Https://Www.Ifes.Org/Sites/Default/Files/ Elections_Postponed_Due_To_Covid-19.Pdf [Accessed 17th July 2020].

${ }^{6}$ Proclamation 3/2020: A State of Emergency Proclamation Enacted to Counter and Control the Spread of COVID-19 and Mitigate its Impact. 2020. 1-4.
} 
unconstitutional government (if the incumbent government continues despite the expiry of its term or if any other interim civilian or military government established). Earlier, on 29 April 2020, the Ethiopian government, to respond to the constitutional crisis, proposed four possible 'options', fait accompli, to get out of the constitutional crisis (Solomon, 2020).

Although any legal measures to postpone election schedule and pass constitutional deadlock was far from simple, the parliament, that day suggested the following solutions to the constitutional dilemma: dissolving the parliament, declaring state of emergency, amendment of the Constitution and constitutional interpretation. Despite objections from some 25 members of the parliament, mainly from Tigray People's Liberation Front (TPLF) ${ }^{7}$, constitutional interpretation was endorsed, and the issue was referred to the Council of Constitutional Inquiry (CCI), "quasiconstitutional court" 8 . The CCI plays merely a legal advisory role to the Ethiopian Upper House, the House of Federation ( $\mathrm{HoF}$ ), that is empowered to interpret the Ethiopian constitution.

On 11 June 2020, the HoF fully adopted the recommendations made by the CCI over the constitutional matters referred to it for interpretation by the Parliament. Finally, the CCI recommended the deferred general elections to be postponed indefinitely until COVID-19 pandemic no longer poses a risk to public health confirmed by the parliament, which has direct vested interest in the outcome 9

The verdict of the HoF to postpone the election indefinitely, however, raises concerns whether the decision regards the premise of the Ethiopian Constitution. This research evaluates whether constitutional interpretation does adhere to the premises of the Ethiopian Constitution or is it extra constitutional and the paper will scrutinise its pitfalls.

\section{Elections during Emergencies: Experiences of Constitutional Provisions of Some States}

Although deadlines for holding elections are often entrenched in a country's legal or constitutional framework, international law allows for the derogation of some rights - including the right to vote and stand for election - in emergency situations with stringent rules to prevent abuse (Katherine, 2020). Some countries have either constitutional provisions or/and legal rules to entertain election postponements due to emergency situations (Choudhry, 2017). During state of emergency, the Indian

\footnotetext{
${ }^{7}$ Later TPLF, a party that administers one of the ten regions of Ethiopia, waged full scale war with the federal government over the disagreement of the election postponement and held its own regional elections.

${ }^{8}$ The Council of Constitutional Inquiry, "Quasi-Constitutional Court", is established by virtue of Art. 82 of the Constitution of the Federal Democratic Republic of Ethiopia and by Proclamation No. 798/2013 to conduct constitutional inquiries and present its findings to the House of the Federation, which is empowered to interpret the Constitution.

9 The Ethiopian House of Federation convenes for the second year of its $5^{\text {th }}$ parliamentary term on June 11 , 2020. Available at: http:/www.hofethiopia.gov.et/web/guest/decisions-documents//document/preview/29608/ 21536. The CCI recommended the deferred general elections to be held within nine to twelve months after the Ethiopian Ministry of Health, the Ethiopian Public Health Institute and the science community assure that the pandemic no longer poses a risk to public health and Parliament approves their suggestion.
} 
Constitution for example, allows Parliament's term of office to be extended by law for a period not exceeding one year at a time and not extending in any case beyond a period of six months after the Proclamation has ceased to operate ${ }^{10}$. The Bangladesh constitution, if the Republic is engaged in war, also allows the term of office of the parliament, without holding elections, to be extended for not more than one year but it shall not be extended beyond six months after the termination of the war ${ }^{11}$. In case of serious crisis, the Cameroon Constitution allows election postponement and asserts that the election of a new Assembly shall take place not less than forty days and not more than one hundred and twenty days following the expiry of the extension or abridgement period (Malah, 2009). The Constitution of Estonia also prohibits the election of members of the new parliament during state of emergency nor shall authority of the existing one be terminated, and elections must be held within three months after the end of the war or emergency ${ }^{12}$. Whereas the Constitution in Myanmar explicitly provides that after the expiry of the incumbent term, the President and the VicePresidents shall continue their duties until the time the new President is duly elected but no similar provision exists for members of Parliament ${ }^{13}$. According to the legislation of Armenia, no referendum can take place during the period of the state of emergency: as a result a constitutional referendum scheduled for April 5/2020 was postponed in Armenia as the country declared a state of emergency to deal with the Coronavirus pandemic ${ }^{14}$.

Thus, states having constitutional provisions or legal frameworks to entertain election postponement, can easily pass emergency situations, which would otherwise have paved the way for constitutional lacuna and conflicts among competing groups.

Any election is by nature rule-based exercises, and changing the rules too close to the game, or without regard to flow-on effects, can be damaging and illegitimate (Katherine, 2020). It is inescapable in some contexts that decisions to postpone or modify election periods and modalities will become politicised and heavily contested. This is even true in democratic states let alone in a country like Ethiopia, which suffers from a democratic deficit and demonstrates many polarised interests.

\footnotetext{
${ }^{10}$ Voting from Abroad: The International IDEA Handbook. (2020), pp. 12-13, 19-20, 23 and 26. Available at: https://Www.Idea.Int/Publications/Catalogue/Votingabroad- International-Idea-Handbook [Accessed $17^{\text {th }}$ July 2020$]$.

11 The Constitution of the People's Republic of Bangladesh, Art.72(3). Available at: https://www.refworld.org/pdfid/3ae6b5684.pdf [Accessed 18 th July 2020].

12 The 1992 Estonia Constitution, Art.131 [Authority During State of Emergency]:

(1) During a state of emergency or a state of war there shall be no elections for the Parliament, the President of the Republic or representative bodies of local government, nor can their authority be terminated.

(2) The authority of the Parliament, the President of the Republic, and representative bodies of local government shall be extended if they should end during a state of emergency or state of war, or within three months of the end of a state of emergency or state of war. In these cases, new elections shall be declared within three months of the end of a state of emergency or a state of war. Available at: http://www.concourt.am/armenian/ legal_resources/world_constitutions/constit/estonia/estoni-e.htm [Accessed $18^{\text {th }}$ July 2020].

13 The 2008 Constitution of Myanmar, Art. 61(b). Available at: http://extwprlegs1.fao.org/docs/pdf/ mya132824.pdf [Accessed 18th July 2020].

${ }_{14}$ Constitutional Referendum Postponed as Armenia Declares State of Emergency, Asbarez Staff, 2020. Available at: http://asbarez.com/193019/constitutional-referendum-postponed-as-armenia-declares-state-ofemergency/ [Accessed $18^{\text {th }}$ July 2020].
} 
The responsibility for making these difficult legal and operational decisions regarding the postponement or modification of elections varies between countries and can become fraught with problems, especially where the legal basis for postponement is not clear cut.

The Venice Commission's Code of Good Practice in Electoral Matters affirms that "stability of the law is crucial to credibility of the electoral process" and recommends no legal changes in the year prior to an election ${ }^{15}$. The International Foundation for Electoral Systems (IFES) in its, according to Katherine (2020), Guidelines and Recommendations for Electoral Activities during the COVID-19 Pandemic has also to note the following legal elements to consider in relation to election postponements and modifications:

- Source of authority for setting or moving election dates

- Legal or constitutionally mandated deadlines for transfers of power

- Provisions for continuity of power beyond the end of a term, or for caretaker governments

- Legal or constitutional authority for temporary derogation of rights or postponement of elections in emergency situations

- Laws or regulations enabling flexibility or modification of methods or modes of carrying out election processes

- Set timelines in the legal framework for key electoral processes such as voter registration, candidate registration and campaigning

- Statutory authority for Election Management Bodies (EMB) to develop regulations and procedures

- Provisions in the legal or regulatory framework requiring certain forms of accessibility, inclusion or consultation.

When states, in the interest of public health, are unable to hold elections, which touch upon citizens' fundamental rights, and are crucial to facilitating peaceful and democratic transfers of power, they are obliged to exhaust different legal means to postpone elections and/or create platforms for inclusive participation of all political parties (Binder, 2020).

\section{The Constitutionality of Election Postponement in Ethiopia}

Coming to Ethiopia, the Ethiopian Constitution stipulates that the members of the House of Peoples Representatives, Ethiopian Lower House, are elected by the people for a term of five years on the basis of universal suffrage and by direct, free, and fair elections held by secret ballot ${ }^{16}$. The Ethiopian Constitution (under Art. 58) also

\footnotetext{
${ }^{15}$ Guidelines and Explanatory Report of the European Commission for Democracy Through Law (Venice Commission). No. 190/2002, Code of Good Practice in Electoral Matters. October 30, 2002.

Accordingly, one way of avoiding manipulation is to define in the Constitution or in a text higher in status than ordinary law the elements that are most exposed (the electoral system itself, the membership of electoral commissions, constituencies or rules on drawing constituency boundaries). Another, more flexible, solution would be to stipulate in the Constitution that, if the electoral law is amended, the old system will apply to the next election - at least if it takes place within the coming year - and the new one will take effect after that.

${ }^{16}$ The Constitution of the Federal Democratic Republic of Ethiopia. 1995. Proc. No. 1. Neg. Gaz. Year 1st, No. 1, Art. 54.
} 
obliges elections for new members of the parliament to be concluded one month prior to the expiry of the House's term without any exception. The current members of the Parliament were elected five years ago in May 2015 and their term of office terminated at the end of August 2020, before another election was held. As per the Ethiopian constitutional provisions, the next national election was supposed to be held before September 2020. Of course, it was scheduled for 29 August 2020 had it not been for COVID-19 pandemic. But the declared state of emergency, due to COVID-19 pandemic, had altogether postponed indefinitely the planned election.

Except stating that there will be a regular national election to be held for every five years, the Ethiopian Constitution does not have any provision to entertain election postponement. ${ }^{17}$ The Constitution, the supreme law of the land, imposes a duty to inter alia all organs of state, political organizations as well as their officials to ensure observance of the Constitution and to obey $\mathrm{it}^{18}$. Thus, the government's decision to postpone the election was not constitutional as any law or a decision of an organ of state or a public official, which contravenes the Constitution shall be of no effect. The Constitution also prohibits assuming state power in any manner other than that provided under the Constitution ${ }^{19}$.

If there is a force majeure to extend the election in an extra constitutional manner, it should be decided by an independent organ that has the consent of all competing political forces or with inclusive participation of all political parties (Anthony, 2020). The government, when it comes to elections, is one of the actors, not the sole decision maker. One can also argue that the absence of constitutional provisions to postpone the election schedule was made intentionally by the architects of the Constitution. This is because the Constitution was drafted after long years of civil wars and it aimed to prohibit any incumbent government from extending its term limit under the guise of an election postponement provision. The postponement of the election in Ethiopia creates a constitutional crisis and unfolds in a legal vacuum. The state of emergency, due to the pandemic, comes at a precarious time for Ethiopia's short lived (democratic) transition in which the country is already struggling to meet the expectations of its population.

\section{Is the State of Emergency used as a Ground to Postpone Election in Ethiopia?}

The Council of Ministers of the Federal Government has the power to declare a state of emergency, should an external invasion, a breakdown of law and order which endangers the constitutional order and which cannot be controlled by the regular law

\footnotetext{
${ }^{17}$ Ethiopian Constitution, Art. 54.

${ }^{18}$ Ethiopian Constitution, Art. 9; The Constitution obliges any official, institutions and practices to observe the premises of its provisions as follows: the Constitution is the supreme law of the land, any law, customary practice or a decision of an organ of state or a public official which contravenes this Constitution shall be of no effect. All citizens, organs of state, political organizations, other associations as well as their officials have the duty to ensure observance of the constitution and to obey it. It is prohibited to assume state power in any manner other than that provided under the Constitution.

${ }^{19}$ Ethiopian Constitution, Art. 9.
} 
enforcement agencies and personnel, a natural disaster, or an epidemic occur ${ }^{20}$. This part examines whether the above-mentioned grounds - conditions used to declare state of emergency in Ethiopia - can also be used to justify postponing election as the government sought desperately.

From these circumstances, the occurrence of a pandemic can be used as justification to impose a state of emergency which had already been declared on $8^{\text {th }}$ of April 2020 due to COVID-19 until the end of August 2020 unless extended. The parliament can renew every four months successively by a two-thirds majority vote ${ }^{21}$. If the state of emergency had been renewed for another four months i.e., until end of December 2020, still the time would not have been sufficient to handle election. Of course, the Ethiopian Constitution neither puts a maximum limit on the number of renewals of an emergency decree nor mentions circumstances to extend. Here the 'state of emergency' was also anticipated by the government to justify election postponement as well. But election postponement is not one of the grounds, under the Ethiopian Constitution or the electoral law, to declare state of emergency and cannot be used to extend the term of the parliament beyond allotted time. There should be some legitimate and constitutionally accepted cause (other than election postponement) to the result (i.e., to declaring state of emergency).

The Ethiopian Constitution also allows declaring state of emergency due to 'a breakdown of law and order which endangers the constitutional order and which cannot be controlled by the regular law enforcement agencies and personnel'. The constitutional crisis that has loomed after September 2020 is not due to any other external forces, i.e., riots and invasions that require state of emergency but emanates either from the very Constitution itself or the constitutional failure to legitimise election postponement. Partly, the absence of any single constitutional provision or any legal framework that addresses explicitly or even impliedly election postponement endangers the constitutional order. Therefore, the constitutional lacuna due to the absence of provisions to handle election postponement cannot be mitigated by declaring a state of emergency. If it is assumed that declaring a state of emergency is the possible way out, it is impossible to hold an election while the right to movement and assembly, among others, are limited during such extraordinary times ${ }^{22}$. Letting the country stay in a prolonged state of emergency has also its own far-reaching consequences in limiting fundamental human rights and freedoms. Thus, declaring a state of emergency, even with sufficient reasons, cannot create a conducive

\footnotetext{
${ }^{20}$ Ethiopian Constitution, Art. 93.

${ }^{21}$ Ethiopian Constitution, Art. 93(3) A state of emergency decreed by the Council of Ministers, if approved by the House of Peoples' Representatives, can remain in effect up to six months. The House of Peoples Representatives may, by a two-thirds majority vote, allow the state of emergency proclamation to be renewed every four months successively.

22 Ethiopian Constitution, Art. 93. The exclusive listing of non-derogable rights during state of emergency under the Ethiopian Constitution are: art 1 which describes the nomenclature of the state 'the Federal Democratic Republic of Ethiopia'; article 18 which prohibits inhumane treatment; article 25 which guarantees equality of everyone before the law and equal protection of the law and articles 39 (1 and 2) which guarantee every nation, nationality and people in Ethiopia to have an unconditional right to self-determination, including the right to secession.
} 
environment to handle elections except extending the term of office of the incumbent government whose term limit is expired.

The last, but not least, ground to declaring state of emergency under the Ethiopian Constitution is the 'external invasion' and is not worth mentioning here as there is not any such threat to the country. A state, even fighting at war, may hold elections and Ethiopia did not postpone the 2000 national elections while it was at full scale war with its neighboring Eritrea between 1998 and 2000.

Some argue that using its executive order granted by the state of emergency provision under Art 93(4) (C) of the Constitution, the government can suspend Art. 54(1) and 58(3) which fix the five years term of the parliament and pass decisions to order the term of the parliament from being terminated. It would be constitutional if the election is going to be postponed due to the state of emergency within the term limit of the parliament. Otherwise, there would have been any constitutional provision exhausting unforeseen circumstances to entertain election postponement.

Because there is a plethora of evidence that shows the direct correlation between state of emergency and gross human and democratic rights violations including the right to voting, the International Covenant on Civil and Political Rights and other human rights instruments, to which Ethiopia is a party, lay down conditions and requirements for a valid state of emergency ${ }^{23}$.

These documents reiterate that any government resort to emergency powers must ascertain, among others, that there should not be incompatibility of all emergency measures with the state's legal norms and other international obligations ${ }^{24}$. Generally, unlike some countries' constitutions, that foresee impending circumstances during state of emergency that delay elections or put exclusive provision to entertain election postponement, the Ethiopian Constitution does not have any such provisions to justify election postponement. In the absence of any constitutional provisions and legal frameworks, declaring a state of emergency merely to justify election postponement and extend the term limit of the expired parliament is duly unconstitutional. Thus, declaring a state of emergency, to handle the constitutional crisis, is doubling the problem and half the solution and it is not looking for solutions for problems but problems for solutions.

\footnotetext{
${ }^{23}$ The International and Regional Human Rights Instruments do not provide a carte blanche to the States Parties to declare state of emergency by their whims. These treaties (with slight variations) lay down the following conditions and requirements for a valid state of emergency and any government resort to emergency powers must ascertain a) the existence of an exceptional threat to the security of the state or its people; b) that there should not be incompatibility of all emergency measures with the state's other international obligations c) that the emergency measures should not be used in a discriminatory manner; and; $d$ ) that there will not be derogation from fundamental rights, listed as non-derogable rights and e) that the emergency measure must be proportional to the threat posed.

${ }^{24}$ UN General Assembly, International Covenant on Civil and Political Rights, 16 December 1966, United Nations, Treaty Series, vol. 999, p. 171. Available at: https://www.refworld.org/docid/3ae6b3aa0.html [Accessed 24 ${ }^{\text {th }}$ August 2020]; See ICCPR, Art. 4;

Council of Europe, European Convention for the Protection of Human Rights and Fundamental Freedoms, as amended by Protocols Nos. 11 and 14, 4 November 1950, ETS 5. Available at: https://www.refworld.org/ docid/3ae6b3b04.html [Accessed 24 ${ }^{\text {th }}$ August 2020]; see ECHR, Art. 15;

Organization of American States (OAS), American Convention on Human Rights, "Pact of San Jose", Costa Rica, 22 November 1969. see Art.27. Available at: https://www.refworld.org/docid/3ae6b36510.html [Accessed 24 ${ }^{\text {th }}$ August 2020].
} 


\section{Attempting to Validate Election Postponement in Ethiopia: Constitutional Interpretation}

The Ethiopian parliament claimed and proposed that the only possible solution to the constitutional crisis concerning election postponement should be exhausted within the perimeter of the Constitution as opposed to extra constitutional means. So, the parliament has finally endorsed constitutional interpretation, among the four ${ }^{25}$ recommended 'options', as the least complex decision to exit the constitutional quandary. Because the 'application and interpretation' of the Constitution must be under the scope of the Constitution ${ }^{26}$, it obliges the interpreter to have the responsibility and duty to respect and enforce constitutional provisions and premises while giving interpretation. Additionally, the Ethiopian Constitution affirms that the fundamental rights and freedoms (including voting and be elected) shall be interpreted in a manner conforming to the principles of the Universal Declaration of Human Rights, International Covenants on Human Rights and International instruments adopted by Ethiopia $^{27}$. In our case the task of doing interpretation of the Constitution mandates any organ not to intrude the constitutional right to vote and be elected.

Still the incumbent government's decision of requiring constitutional interpretation concerning election postponement in Ethiopia, given the constitutional provisions that fixes the term of the office of any elected parliament to be five years ${ }^{28}$, heated up legal debates on, among others, the following issues:

1. Do the constitutional provisions, governing the period of conducting election and the term of the two Houses as well as the Executive branch, merit constitutional interpretation?

2. Which specific constitutional provisions, if any, are going to be interpreted concerning election postponement?

3. Is the neutrality of the constitutional interpreter conformed, as the HoF has a direct vested interest in the outcome of the decision? This part investigates these mutually exclusive questions.

The first question regarding constitutional interpretation, in the specific case of election deferral, starts from questioning the necessity of the very act of interpreting the FDRE Constitution. This is due to the Constitution having explicit provisions that govern election schedules and determine the term of office of parliament without any exception. The Ethiopian Constitution, for example, states that the members of the House of Peoples Representatives are to be elected for a term of [five] years on the basis of universal suffrage and by direct, free and fair elections ${ }^{29}$. Accordingly, the term of the office of the incumbent parliament, which was elected in May 2015, expired before 10 October 2020 (Meskerem 30).

\footnotetext{
${ }^{25}$ The four options put forward by the administration: dissolving the parliament, declaring a state of emergency, amendment of the FDRE Constitution and constitutional interpretation.

${ }^{26}$ Ethiopian Constitution, Art. 13; Under the scope of application and interpretation, the Constitution obliges all Federal and State legislative, executive and judicial organs at all levels shall have the responsibility and duty to respect and enforce constitutional provisions.

${ }^{27}$ Ethiopian Constitution, Art.13.

${ }^{28}$ Ethiopian Constitution, Art.58 and 54.

${ }^{29}$ Ethiopian Constitution, Art. 54.
} 
While prescribing the meetings of the House and the duration of its term, the Ethiopian Constitution duly sets the term of parliament at [five] years without any exception and reiterates that [elections] for a new House shall be concluded one month prior to the expiry of the House's term ${ }^{30}$. The debate revolves about 'what is not clear about five years' that needs interpretation.

The Ethiopian Constitution asserts its supremacy and denies effect to any law, customary practice or a decision of any organ of the state or a public official that violates $i t^{31}$. As an expression of its supremacy, all citizens, organs of state, political organizations and other associations, as well as their officials, are required to ensure the observance of the Constitution and to obey it. Most importantly, the Ethiopian Constitution serves as the only source of government power. It is, therefore, prohibited to assume power through any means other than, or contradictory to, the manner prescribed in the Constitution itself.

The Ethiopian Constitution, while listing grounds to declare a state of emergency, does not say anything about election postponement if the election schedule occurs amidst such an extraordinary situation ${ }^{32}$. Some argue, citing Art 38 cum 93, that election can be postponed because the Ethiopian Constitution does not list the right to vote and be elected as non-derogable rights during a state of emergency. If an election is not conducted, there will not be a government as per Art.54 cum 93. Ethiopia, given its internal political polarizations and external challenges, should not be left without a government unless the new elected government replaces the outgoing one. But some others still argue that because self-determination is one of the non-derogable rights under the Ethiopian constitution ${ }^{33}$ even during a state of emergency, holding elections as one of the basic manifestations of self-determination cannot be postponed.

Had the Constitution anticipated emergency situations during election periods that could potentially prevent holding elections as per the scheduled timeline, the Constitution would not have such limitations responsible for the current legal crisis. Unfortunately, in Ethiopia, there are neither constitutional provision(s) that anticipate grounds to extend elections nor any proclaimed legal frameworks that govern election delaying or rescheduling during an emergency situation.

It is believed that a holistic understanding of a constitution and a robust interpretation by the responsible body is a necessary means of guaranteeing constitutionalism and making an indisputable and consistent reform [of a constitution] in line with the ever changing conditions of life. However, the Ethiopian ruling Prosperity Party, the only party in the parliament, listed only three constitutional provisions (Art. 54, 58 and 93) that stipulate that the election of Members of the

\footnotetext{
${ }^{30}$ Ethiopian Constitution, Art. 58.

${ }^{31}$ Ethiopian Constitution, Art. 9.

32 Ethiopian Constitution, Art. 93.

${ }^{33}$ Ethiopian Constitution, Art. 93 (4)(C): In the exercise of its emergency powers the Council of Ministers cannot, however, suspend or limit the rights provided for in Art. 1, 18, 25, and sub- Art. 1 and 2 of Art. 39 of this Constitution. The exclusive listing of non-derogable rights during state of emergency under the Ethiopian Constitution are: Art 1 which describes the nomenclature of the state 'the Federal Democratic Republic of Ethiopia'; Art.18 which prohibits inhumane treatment; Art. 25 which guarantees equality of everyone before the law and equal protection of the law and Art. 39 (1 and 2) which guarantees every Nation, Nationality and People in Ethiopia to have an unconditional right to self-determination, including the right to secession.
} 
Parliament, the duration of the term of the Members of Parliament and declaration of the state of emergency respectively are to be interpreted and forwarded to the HoF. Although identifying specific constitutional provisions to be interpreted requires careful and inclusive discussion, the parliament decided this issue in a hurry on 5 May 2020, less than five days after [the parliament] announced the four possible 'options'.

Besides the guidance concerning the meaning of a particular word or phrase that may be expressed in other words and phrases in the same provision or in other provisions of a constitution, constitutional interpretation requires provisions to be construed as a whole. Owing to this, the parliament's prejudgment of ordering only [three] constitutional provisions to be interpreted while there are other potentially relevant provisions raises concerns as to the holistic interpretation of the Constitution. The provisions the government wanted to be interpreted should not be read by excluding other pertinent provisions. This is because depending on a single or two or even three provisions may lead to a hasty generalization.

Art. 102 of the Constitution, which established the Electoral Board, would have been one of the provisions to be referred to, as the Board has confirmed not to hold the planned elections as per its schedule due to the COVID-19 emergency situations. The interpretation did not even consider Art. 9 of the Ethiopian Constitution that prohibits assuming state power 'in any manner' other than provided by the Constitution ${ }^{34}$.

The crux of the debate following the global pandemic — whether periodic election is maintained or postponed - necessitates consideration of not only national legal frameworks but also ratified international legal norms. The importance of periodicity of elections is enunciated under the African Charter on Democracy, Elections and Governance (ACDEG) $)^{35}$ and the International Covenant on Civil and Political Rights (ICCPR) ${ }^{36}$, to which Ethiopia is a party, and which by virtue of Art. 13(2) of the Constitution form part of the human rights chapter of the Constitution. But, the interpretation decision as far as it considers merely Art. 54, 58 and 93 excludes Art. 13 of the FDRE Constitution that requires the bill of rights to be interpreted in a manner conforming to the international instruments adopted by Ethiopia, which [require periodic] election ${ }^{37}$.

It was also a unilateral decision by the parliament, being the judge on its own fate, without even consulting competing political parties, the primary actors in the election process. Of course, some Members of Parliament did not accept the very necessity of constitutional interpretation, citing Art 54 and 58 of the Constitution, which have unequivocal provisions governing election schedule without any exception. Still, Art. 45 of the Constitution should not have been left from being referred to during the interpretation, since it requires the establishment of only a 'parliamentary' form of government in Ethiopia, in response to the opposition parties' call for any form of government (Transition Government, Caretaker Government, Consultative Government, Elite Led Government, etc.) different from what the constitution

\footnotetext{
${ }^{34}$ Ethiopian Constitution, Art. 9 (3).

${ }^{35}$ African Union, African Charter on Democracy, Elections and Governance (ACDEG, Art. 2(3) and 3(4).

30 January 2007. Available at: https://www.refworld.org/docid/493fe2332.html [Accessed 24 ${ }^{\text {th }}$ August 2020].

${ }^{36}$ International Covenant on Civil and Political Rights, Art. 25(B).

${ }^{37}$ Ethiopian Constitution, Art. 13(2).
} 
prescribes. And any attempt to establish such government would have been, of course, understood as contradicting the constitutional provisions.

The third debate, regarding constitutional interpretation in general and concerning the 2020 election postponement in particular, is on the neutrality of the interpreter, which has been a contentious issue since the promulgation of the FDRE Constitution. This is because the Ethiopian Constitution does not establish an effective and independent constitutional adjudication system. The Constitution rather empowers the upper House, the political organ, to interpret the Constitution ${ }^{38}$. Unlike many countries (including Germany, South Africa, USA) which establish a neutral and competent constitutional interpreter either by assigning the constitutional mandate to regular courts or constitutional courts, the Ethiopian Constitution confers the Upper House $^{39}$, which has been controlled by a single party, to interpret the Constitution ${ }^{40}$.

Following the constitutional gaps/crisis, the opposition parties have called for termination of the incumbent parliament, both the Lower and Upper Houses, but parliament requested constitutional interpretation to decide on election postponement, which would determine termination or extension of its term of office. The funny thing is that such action — interpreting the Constitution to decide on the fate of the parliament's termination or extension - is under the discretion of the Upper House, which has direct vested interest in the outcome of the decision. The upper House is not an impartial arbiter on a case involving the term limit of the Lower House, since the decision to extend the latter's term also extends its own. It is explained by the fact that all members of the two Houses in Ethiopia are from the single party, Prosperity Party.

This raises the question whether 'anybody can be the judge of his or her own case? The answer is evident since the Act contradicts the golden rule in legal scholarship - nemo judex in causa sua, no-one is a judge in his own cause. Such a scenario erodes the credibility of the decision of the HoF, and constitutional interpretation has remained a political matter in Ethiopia. After it received the case about election postponement, the $\mathrm{HoF}$ has extended its own term of office and that of the House of Peoples Representatives for unlimited time until election is held within nine to twelve months following the cessation of COVID-19 as confirmed by the Parliament (Anthony, 2020). The decision didn't discuss what should happen if the pandemic continued for another one, three, five or ten years. Furthermore, the final confirmation of the end of the Pandemic Emergency is not given by any independent body but by the parliament which has a direct vested interest in the outcome. The manner the HoF managed the constitutional vacuum concerning election postponement, was 'constitutional interpretation' by name but a political decision in practice.

\footnotetext{
${ }^{38}$ Ethiopian Constitution, Art. 62.

${ }^{39}$ Ethiopian Constitution, Art. 61. Accordingly, the members of the House of the Federation are composed of representatives of Nations, Nationalities and Peoples; each Nation, Nationality and People shall be represented in the House of the Federation by at least one member. Each Nation or Nationality shall be represented by one additional representative for each one million of its population. Members of the House of the Federation shall be elected by the State Councils. The State Councils may themselves elect representatives to the House of the Federation, or they may hold elections to have representatives elected by the people directly. Thus, to be the members of the House of Federation does not require legal scholarship as a criterion but representative role.

${ }^{40}$ Ethiopian Constitution, Art. 83.
} 
Of course, the Ethiopian Constitution has established a Council of Constitutional Inquiry that is assigned to provide legal assistance to the $\mathrm{HoF}^{41}$. The Council of Constitutional Inquiry is composed of eleven members. The nomination and approval of the six legal experts of the Council (apart from the President and Vice-President of the Supreme Court who are ex officio chairperson and deputy chairperson of the Council) are made by the parliament and one can therefore expect them to be loyal to the incumbent government. But what is astonishing is that the remaining three members of the Council are members of the same HoF. The latter three members may or may not be legal experts since their membership does not explicitly depend on their professional competence but on political considerations. Still, the Council has a mere advisory role and its recommendation is not binding; the veto lies with the HoF.

Considering these institutional structures, lack of neutrality of the members and more over the existence of interest conflict over the extension/termination of the election schedule, the neutrality of the constitutional interpretation at the HoF is inherently absent. Therefore, as purely political organ under the influence of the legislature and the executive, given the fusion of power under the Ethiopian two Houses and executives, and the obvious interest of the HoF to extend its own term of office, the $\mathrm{HoF}$ cannot be expected to decide politically sensitive issues independently let alone the issue of election postponement that determines its own term of office. The constitutionality of the election postponement was resisted by some opposition parties ${ }^{42}$ and even by some members of the HoF. ${ }^{43}$ The HoF speaker, Keria Ibrahim, resigned after publicly denouncing the government's decision to seek constitutional interpretation to handle deferred election. The speaker had accused the ruling Prosperity Party of undermining the Constitution and wanting to establish an authoritarian regime ${ }^{44}$.

\section{Prohibition of Abstract Review and Interpretation Ground under the Ethiopian Constitution}

Due to the fact that the perilous situation created by COVID-19 worsened the seemingly looming constitutional crisis in Ethiopia, the incumbent government

\footnotetext{
${ }^{41}$ Ethiopian Constitution, Art. 84.

${ }^{42}$ In order to find a legitimate solution for the impasse through national consensus. The following seven parties had announced and called for political discussion concerning election schedules. 1) The deliberation and negotiation should involve all political parties registered and qualified to participate in the 2020 election. 2) The deliberation and negotiation should be facilitated by entities who do not have direct involvement in election affairs and do not have vested interest in the outcome. 3) The final agreement reached among parties should be binding. Cosigning members of the Coalition of Democratic Federalism: Oromo Liberation Front, Ogaden Liberation Front, Oromo Federalist Congress, Agaw National Congress, Mocha Democratic Party, Kaffa Green Party, Arena Tigray for Democracy and Sovereignty.

${ }^{43}$ Members of the HoF in its 5th year, second regular session of the chamber, on 10 June 2020, approved the CCI's recommendations submitted to the constitutional interpretation and identity sub-committee on May 29. The House approved the recommendation with 114 votes in favour to 4 votes against with one abstention. See Addis Fortune.

${ }^{44}$ Of course, it should be noted here that Keria was a member of the TPLF and therefore had its own political reasons - rather than a genuine concern about constitutionalism - to resist this approach. Available at: Http://Addisstandard.Com/News-Alert-Hof-Approves-Ccis-Recommendation-To-Extend-Both-Houses-StateCouncils-Term-Limit-Constitutional-Expert-Raises-Concern/ [Accessed 24th August 2020].
} 
desperately looked for leeway to postpone the sixth national election under the guise of constitutional interpretation. However, the constitutional interpretation option was rather unconstitutional in itself for two simple constitutional reasons: the absence of interpretation ground (disputed issue) and the prohibition of abstract review.

Interpretation Ground: In general, legal interpretation including the constitution takes place where there are justifiable grounds such as - vagueness, silence and contradiction (Randall, 1994). Hence, the main inquiry should be whether the provisions under question - Art. 54 (1), Art. 58 (3) and Art. 93 - show any of these three grounds.

A. Vagueness - When a given word or phrase in the law/constitution is unclear or vague, it calls for interpretation by the institution formally bestowed with the power to do so (Guyora, 2019). Art. 54 (1) and Art. 58 (3) explicitly state and limit the term of the HPR to five years without exception and Art. 93 unambiguously lists grounds, other than election postponement, for declaration of state of emergency: “...external invasion, a breakdown of law and order which endangers the Constitutional order, and which cannot be controlled by the regular law enforcement agencies and personnel, a natural disaster, or an epidemic". In the current case, there is no vague constitutional provision, which warrants constitutional interpretation by the HoF.

B. Contradiction - The second ground that brings constitutional interpretation to the fore is when two constitutional provisions are apparently contrary to each other at least textually ${ }^{45}$. Again, in the case at hand, there are no seemingly contradictory provisions.

C. Silence - This ground calls for interpretation of the matter(s) on which the Constitution kept silent or left it unregulated. Now the question is, whether the Constitution is silent on the extension of term limits? The answer is emphatically no. Because, the Constitution has spoken in loud and clear volume when it comes to prohibition of extension of term limit. Art. 9(3) clearly rules out the assumption or continuation of power other than by means and procedures laid down under the constitution. And election is the only constitutional avenue to assume power, which the Ethiopian Constitution stipulates as there will be regular elections for every five years $^{46}$. Declaring state of emergency as per Art. 93 (1) (a) also cannot be used to extend the tenure of the parliament beyond five years as specified under Art. 54 (1). Therefore, there are no justifiable constitutional interpretation grounds in this case that merit constitutional interpretation. This sounds as there are no justifiable constitutional interpretation grounds in this case that would deem constitutional interpretation.

\section{The Prohibition of Abstract Review under the Ethiopian Constitution}

In this regard, constitutional interpretation can be roughly bifurcated into two (Wojciech, 2002). These are abstract review and concrete review procedures. While the former refers to seeking interpretation for the matter, which has not been contested, the latter applies to case(s) where constitutional dispute arises between litigant parties.

\footnotetext{
${ }^{45}$ Ethiopian Constitution, Art. 84 (2).

${ }^{46}$ Ethiopian Constitution, Art. 54.
} 
Broadly speaking, in Ethiopia, abstract review or advisory opinion mode of interpretation has not been permissible ${ }^{47}$. Evidence for this is Art. 37. The Ethiopian Constitution states unequivocally that it is only justiciable (not abstract issues) matter that can be brought to adjudicatory institutions in Ethiopia. The relevant constitutional provisions (read Art.62 cum 83), which define power of constitutional interpretation also make it abundantly clear that the interpretational power of HoF is limited only to constitutional disputes (that's concrete review). Besides, the existing president in Ethiopia makes no space or possibilities for abstract reviews (an example for this include: Dr. Negaso's case - his claim against the proclamation that prohibits benefits to retired or resigned President if $\mathrm{s} / \mathrm{he}$ joins an opposition political party. And also, the Oromia regional state's request for interpretation of the 'special interest on Addis Ababa' under the constitution (Solomon, 2020). The Proclamation No 798/2013 regulating the $\mathrm{CCI}$ has no provision authorizing the $\mathrm{CCI}$ to issue a consultative or advisory opinion.

The fact that the HoF and CCI do not have consultancy or advisory service, the very request of the House of Peoples Representatives for [constitutional guidance] on the postponement of the national election and subsequent matters is not supported by the Constitution or any relevant proclamations ${ }^{48}$. Hence, based on the preceding legal analysis one can safely and soundly conclude that both the procedure and the constitutional interpretation option apparently preferred by the Parliament is an unconstitutional alternative.

\section{Conclusion}

As far as elections are postponed beyond the scheduled plan, even if the constitutional interpretation was a legal remedy as maintained by the ruling government, questions arise as to the legitimacy of office holders. The postponement of the scheduled election under the patronage of constitutional interpretation, contended by legal experts and political parties, was unconstitutional, whereas the HoF decision was constitutional interpretation by name but political decision in practice. Thus, the constitutionality of election postponement in Ethiopia, in the absence of clear constitutional provision, is not duly legalised.

The major flaws of the constitutional interpretation to postpone the election in August 2020 are as follows:

- The CCI stated the textual reading of Art. 58(3) of the Constitution implies the contingency of the Parliament's five-year term on whether an election is held at least a month before the expiry of the term. This is an absurd inference as the meaning of the text is plain and drafted in compulsory terms.

- The CCI held that the purposive reading of Art. 93 of the Constitution indirectly recognises that the incumbent Government's term limit may exceed five years. The CCI provided no reasons for this statement. Instead, the CCI made the fallacy of circular reasoning by starting with the premise that it ended up repeating as a conclusion.

\footnotetext{
${ }^{47}$ Ethiopian Constitution, Art. 37.

${ }^{48}$ Ethiopian Constitution, Art. 37(1), 62(1), 83(1), 84 (1 and 2) and Proclamation No 798/2013.
} 
- The CCI gives the Federal Ministry of Health (FMOH) a central role in determining when the postponed election resumes. The National Electoral Board of Ethiopia is a constitutionally mandated organ to decide such important election-related matters. It contravenes the spirit of the Constitution to reassign this power to the executive branch. The incumbent can stay in power as long as it says COVID-19 continues to be a public danger.

- The CCI held that the mandate of the regional councils and executive bodies shall also be extended as well as that of the federal parliament and government because elections matters are federal issues. The CCI enmeshed the decision to postpone elections with the decision regarding the terms of the regional council and governments. The former is a federal matter, while the latter is undoubtedly a matter left to the regional constitution. Hence, this aspect of the decision encroached upon jurisdiction of regional governments.

The Way Forwarding. The CCI has rewritten the Constitution under the guise of interpretation. The destabilizing effect of a failure to successfully tackle the current crisis can only contribute to further deterioration in an already fragile transition in Ethiopia. To amicably manage an impending constitutional and political crisis the discussion between the government and opposition parties within the constitutional framework would have been vital. In the short run, the political dialogue and consensus building — in the absence of a constitutional remedy - remains the only real avenue for resolution of the crisis. Given the internal political polarizations and external challenges, a short period of government led transition, with its limitations, would have been one of the least evil options until the next election are held. In the long run, the Ethiopian Constitution needs to be amended since it does not indisputably govern election postponement during state of emergency and the amended version should consider conditions during state of emergency that prevent expiration of the term of the parliament and that allow it to be extended for fixed period of time until the exigencies end.

\section{References}

Anthony, B. (2020) Elections and COVID-19: Legal Consideration as a way out. International Foundation for Electoral Systems. 1-10.

Antonio, S. (2020) Managing Elections Under The COVID-19 Pandemic: The Republic of Korea's Crucial Test, International Institute for Democracy and Electoral Assistance (IDEA), Technical Paper, 1-8. DOI: 10.31752/Idea.15

Binder, K. et al. (2020) States of Emergency in Response to the Coronavirus Crisis: Situation in Certain Member States, EPRS. Available at: https://www.europarl.europa.eu/RegData/ etudes/BRIE/2020/649408/EPRS_BRI(2020)649408_EN.pdf [Accessed 23 ${ }^{\text {rd }}$ August 2020].

Choudhry, S. (2017) Transnational Constitutionalism and a Limited Doctrine of Unconstitutional Constitutional Amendment. International Journal of Constitutional Law. 15 (3), 23-34.

Davide, E. (2019) From an Unconstitutional Constitutional Amendment to an Unconstitutional Constitution? Lessons from Honduras. Global Constitutionalism. Cambridge University Press. 8 (1), pp. $40-70$.

Guyora, B. \& Brenner, M. (2019) Fissell. A Political Interpretation of Vagueness Doctrine. UNIV. OF ILL. L. REV. 1527, pp. 1-63. Available at: https://scholarlycommons.law.hofstra.edu/ faculty_scholarship/1254 [Accessed $21^{\text {st }}$ August 2020]. 
Katherine, E. (2020) The Legal Quagmire of Postponing or Modifying Election. International Foundation for Electoral Systems. Available at: https://www.ifes.org/news/Legal-QuagmirePostponing-Or-Modifying-Elections [Accessed 23 ${ }^{\text {rd }}$ August 2020].

Katherine, E. (2020) Legal Considerations When Delaying or Adapting Elections. International Foundation for Electoral Systems. Available at: https://www.ifes.org/sites/default/files/ ifes_covid-19_briefing_series_legal_considerations_when_delaying_or_adapting_elections _ june_2020.pdf [Accessed 23 $3^{\text {rd }}$ August 2020].

Malah, A. (2009) Constitutional Protection in Cameron: Critique of the Amendment Mechanism. MA Thesis, Central European University.

Randall, K. (1994) Styles of Constitutional Interpretation and the Four Main Approaches to Constitutional Interpretation in American Legal History. 29 Val. U. L. Rev. (121), $121-233$.

Sead, A. \& Matatu, N. (2019) Timing and Sequencing of Transitional Elections. International IDEA Policy Paper. (18), 1-61. DOI: 10.31752/idea.2019.13

Solomon, A. (2020) Constitutional Based National Dialogue the Best Way to Avert a Constitutional Crisis Triggered by Deferred Election. Addis Standard, Op-Eds.

Solomon, A. et al. (2020) Joint Submission to the Constitutional Council of Inquiry of the Federal Democratic Republic of Ethiopia on the Matter of the House of Peoples' Representative Request for Constitutional Interpretation, CCI. Available at: http://Addisstandard.Com/ Op-Ed-Constitutional-Based-National-Dialogue-The-Best-Way-To-Avert-A-ConstitutionalCrisis-Triggered-By-Differed-Election/ [Accessed 23 ${ }^{\text {rd }}$ August 2020].

\section{About the author:}

Marew Abebe Salemot - Lecturer of Federalism, Debark University; 90 Debark, Gonder, Ethiopia

ORCID ID: 0000-0003-2612-6923

e-mail: marewobu@gmail.com

\section{Об авторе:}

Салмот Марев Абебе - преподаватель, Университет Дебарка; Эфиопия, г. Дебарк, Гондер, д. 90

ORCID ID: 0000-0003-2612-6923

e-mail: marewobu@gmail.com 